\title{
Determination of Isoniazid by Fe(II)-2,2'-Bipyridine Spectrophotometry
}

\author{
Changqing $\mathrm{Tu}^{1}$ and Xinrong Wen ${ }^{* 1}$ \\ ${ }^{1}$ School of Chemistry and Environment, Jiaying University, Meizhou, Guangdong 514015, China \\ Guangdong Provincial Key Laboratory of Conservation and Precision Utilization of Characteristic \\ Agricultural Resources in Mountainous Areas, Jiaying University, Meizhou, Guangdong 514015, China
}

\begin{abstract}
In acidic media, $\mathrm{Fe}(\mathrm{W})$ could be reduced to $\mathrm{Fe}(\mathrm{II})$ by isoniazid, $\mathrm{Fe}(\mathrm{II})$ reacts with 2,2'-bipyridine to form an orange complex with a maximum absorption wavelength of $522 \mathrm{~nm}$. According to this principle, the content of isoniazid can be measured indirectly by measuring the amount of $\mathrm{Fe}(\mathrm{II})$. A new method for the determination of isoniazid by Fe(II)-2,2'-bipyridine spectrophotometry has been established. At the optimum conditions, the linear relationship is good between the mass concentration of isoniazid and absorbance of $\mathrm{Fe}(\mathrm{II})-2,2^{\prime}$-bipyridine complex in the range of $0.0004000-0.002800 \mathrm{mg} / \mathrm{mL}$. The linear regression equation is $\mathrm{A}=0.0251+138.04 \mathrm{C}(\mathrm{mg} / \mathrm{mL})$, and the linear correlation coefficient is 0.9995 . This method is used to determine the content of isoniazid in isoniazid tablets, and the results are similar to those obtained by pharmacopoeia method.
\end{abstract}

\section{Introduction}

Isoniazid (the structure is shown in Figure 1) is mainly as one of the preferred drugs for effective treatment of various tuberculosis in clinical practice. But it has drug resistance, and can cause liver damage during the treatment process. Therefore, it is of great importance and significance for the determination of isoniazid content. So far, spectrophotometry[1-2], fluorescence spectrum method[3], flow-injection chemiluminescence analysis[4], capillary electrophoresis analysis[5-6], GC[7], HPLC [8-9], electrochemical method[10-11], and so on have been applied for the determination of isoniazid.<smiles>NNC(=O)c1ccncc1</smiles>

Fig. 1. The molecular structure of isoniazid

A new method for the determination of isoniazid by $\mathrm{Fe}(\mathrm{II})-2,2$ '-bipyridine spectrophotometry has been established. The various factors affecting the determination of isoniazid content are investigated. The results show that in acidic media, $\mathrm{Fe}(\amalg)$ could be reduced to $\mathrm{Fe}(\mathrm{II})$ by isoniazid, $\mathrm{Fe}(\mathrm{II})$ reacts with 2,2'bipyridine to form an orange complex with a maximum absorption wavelength of $522 \mathrm{~nm}$. At the optimum conditions, the linear relationship is good between the mass concentration of isoniazid and absorbance of $\mathrm{Fe}(\mathrm{II})-2,2$ '-bipyridine complex, the content of isoniazid can be measured indirectly by measuring the amount of $\mathrm{Fe}(\mathrm{II})$. In the range of $0.0004000-0.002800 \mathrm{mg} / \mathrm{mL}$, the linear regression equation is $\mathrm{A}=0.0251+138.04 \mathrm{C}$ $(\mathrm{mg} / \mathrm{mL})$, and the linear correlation coefficient is 0.9995 . This method is used to determine the content of isoniazid in isoniazid tablets, and the results are satisfactory.

\section{Experimental}

\subsection{Equipment and reagents}

723S spectrophotometer (Shanghai Precision \& Scientific Instrument Co,. Ltd ) is used for photometric measurements. UV-2401 UV-visible spectrophotometer (The Shimadzu Corporation, japan) is used for scanning the absorption spectrum.

Isoniazid standard solution: $0.1000 \mathrm{mg} / \mathrm{mL} . \mathrm{Fe}^{3+}$ solution: $\quad 0.1000 \mathrm{mg} / \mathrm{mL}$, is prepared by $\mathrm{NH}_{4} \mathrm{Fe}\left(\mathrm{SO}_{4}\right)_{2} \cdot 12 \mathrm{H}_{2} \mathrm{O}$ and appropriate amount of 3.0 $\mathrm{mol} / \mathrm{L} \quad \mathrm{H}_{2} \mathrm{SO}_{4} \quad$ solution. 2,2'-bipyriddine (BPY) solution:0.01998 moL/L. Buffer solutions of different $\mathrm{pH}$ was prepared as references 12 .

All reagents are analytical reagent. Bidistilled water is used throughout.

\subsection{Method}

A given volume of $0.1000 \mathrm{mg} / \mathrm{mL}$ isoniazid standard solution or sample solution, $0.2000 \mathrm{mg} / \mathrm{mL} \mathrm{Fe}^{3+}$ solution $1.40 \mathrm{~mL}$ are added into a $25 \mathrm{~mL}$ ground color comparison tube, added water to $10.00 \mathrm{~mL}$ and mixed well. Aftering this mixture reacted for $30 \mathrm{~min}$ at $80^{\circ} \mathrm{C}$ in water both and cooled back to room temperature, $0.01998 \mathrm{moL} / \mathrm{L} 2,2^{2}$-bipyridine solution $0.30 \mathrm{~mL}$ and

*Corresponding author: 198601012@jyu.edu.cn 
$\mathrm{pH}=5.0$ buffer solution $4.00 \mathrm{~mL}$ are added. The solution is diluted to $25.00 \mathrm{~mL}$ and mixed well, then, the absorbance is measured at $522 \mathrm{~nm}$ against the reagent blank after placing $10 \mathrm{~min}$.

\section{Results and discussion}

\subsection{Maximum absorption wavelength}

According to the experimental method, the absorption spectrum(400-600 nm) of Fe(II)-2,2'-bipyridine orange complex is shown in Figure 2. The maximum absorption wavelength of $\mathrm{Fe}(\mathrm{II})-2,2$ '-bipyridine orange complex is at $522 \mathrm{~nm}$. So, the absorption wavelength $522 \mathrm{~nm}$ is selected.

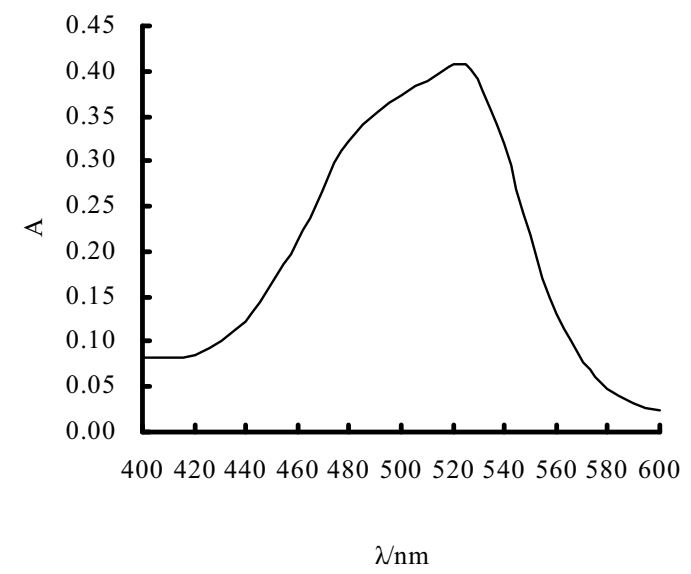

Figure 2. Absorption spectrum

Isoniazid solution: $0.30 \mathrm{~mL} ; \mathrm{Fe}^{3+}$ solution: $1.40 \mathrm{~mL}$; BPY solution:0.30 mL; pH 5.0 buffer solution:5.00 mL; reaction temperature: $80^{\circ} \mathrm{C}$; reaction time: $20 \mathrm{~min}$; placing time: $15 \mathrm{~min}$.

\subsection{Reaction temperature}

The effect of reaction temperature on absorbance is seen in table 1. It can found that the absorbance of solution reaches greatest and almost constant when the reaction temperature is $70 \sim 100^{\circ} \mathrm{C}$. Hence, $80^{\circ} \mathrm{C}$ is used.

Table 1 Relationship between the reaction temperature and the absorbance

\begin{tabular}{ccccc}
\hline Temperature $/{ }^{\circ} \mathrm{C}$ & 30 & 40 & 50 & 60 \\
\hline Absorbance & 0.126 & 0.138 & 0.143 & 0.147 \\
Temperature $/{ }^{\circ} \mathrm{C}$ & 70 & 80 & 90 & 100 \\
Absorbance & 0.158 & 0.159 & 0.158 & 0.160 \\
\hline
\end{tabular}

\subsection{Reaction time and placement time}

The relationship between the reaction time and the absorbance can be seen in table 2. It is found that the absorbance of solution reaches greatest and keeps constant when the reaction time is $30 \sim 60 \mathrm{~min}$. Therefore, $30 \mathrm{~min}$ has been chosen.
Table 2 Relationship between the reaction time and the absorbance

\begin{tabular}{ccccc}
\hline Time/min & 5 & 10 & 15 & 20 \\
\hline Absorbance & 0.159 & 0.158 & 0.159 & 0.161 \\
TimeT/min & 30 & 40 & 50 & 60 \\
Absorbance & 0.168 & 0.166 & 0.166 & 0.165
\end{tabular}

When the placement time is $5 \sim 120 \mathrm{~min}$, the experimental results of placement time on absorbance show that the absorption is not affected by the placement time. Thus, the placement time is selected for $10 \mathrm{~min}$.

\section{$3.4 \mathrm{pH}$ buffer solution and its dosage}

The effects of $\mathrm{pH}$ buffer solution on absorbance are considered. The results show that the absorbance of solution are maximal and remain almost constant when the $\mathrm{pH}$ is $3.6 \sim 5$.6. Consequently, $\mathrm{pH} 5.0$ buffer solutions is used.

The experimental results of the dosage of $\mathrm{pH} 5.0$ buffer solution on absorbance showed that the absorbance reaches its maximum value and remains constant when the dosage of pH5.0 buffer solution is $3.00 \sim 8.00 \mathrm{~mL}$. Therefore, the optimum dosage of $\mathrm{pH}$ buffer solution is $4.00 \mathrm{~mL}$.

\subsection{The dosage of 2,2'-bipyridine}

The effect of the dosage of 2,2'-bipyridine can be seen in Figure 3. From Figure 3, we can see that the absorbance reaches its maximum value and keep basically unchanged when the dosage of 2,2'-bipyridyl is 0.20 $0.60 \mathrm{~mL}$. So, $0.30 \mathrm{~mL}$ is identified as the optimum dosage of 2,2'-bipyridine.

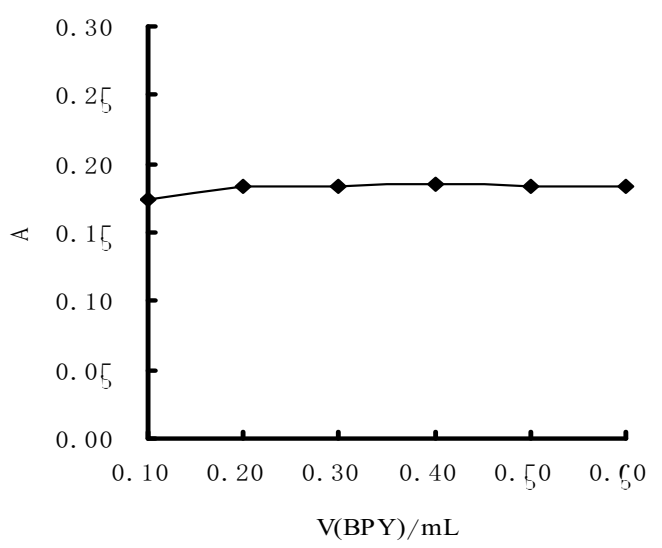

Figure 3. Effect of the dosage of 2,2'-bipyridine Isoniazid solution: $0.30 \mathrm{~mL} ; \mathrm{Fe}^{3+}$ solution: $1.40 \mathrm{~mL} ; \mathrm{pH} 5.0$ buffer solution: $4.00 \mathrm{~mL}$; reaction temperature: $80^{\circ} \mathrm{C}$; reaction time:30 min; placing time: $10 \mathrm{~min}$.

\subsection{The dosage of $\mathrm{Fe}(\mathrm{III})$}

The relationship between the the dosage of Fe(III) and the absorbance is showed in Figure 4. It is found that the 
absorbance reaches greater and remains constant when the dosage of Fe(III) is $1.20 \mathrm{~mL} \sim 1.60 \mathrm{~mL}$. So, $1.40 \mathrm{~mL}$ of $\mathrm{Fe}(\mathrm{III})$ is employed.

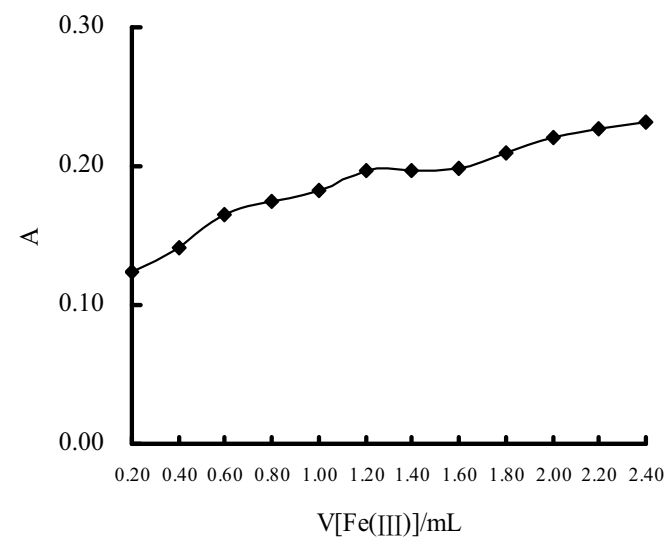

Figure 4. Effect of the dosage of Fe(III)

Isoniazid solution: $0.30 \mathrm{~mL}$; BPY solution: $0.30 \mathrm{~mL}$; $\mathrm{pH} 5.0$ buffer solution: $4.00 \mathrm{~mL}$; reaction temperature: $80^{\circ} \mathrm{C}$; reaction time:30 min; placing time: $10 \mathrm{~min}$.

\subsection{Standard curve}

According to the experimental method, under the selected conditions $\left(0.2000 \mathrm{mg} / \mathrm{mL} \mathrm{Fe}{ }^{3+}\right.$ is $1.40 \mathrm{~mL}$, $0.01998 \mathrm{~mol} / \mathrm{L} 2,2^{\prime}$ - bipyridine is $0.30 \mathrm{~mL}, \mathrm{pH} 5.0$ buffer solutions is $4.00 \mathrm{~mL}$, reaction temperature is $80^{\circ} \mathrm{C}$, reaction time is $30 \mathrm{~min}$, placement time is $10 \mathrm{~min}$ ), the different concentration of isoniazid standard solutions are prepared and the absorbances of these solutions are measured at $522 \mathrm{~nm}$ against the reagent blank. Then draw with concentration as horizontal coordinate and absorbance as vertical coordinate, the standard curve is showed in Figure 5. In the range of 0.0004000-0.002800 $\mathrm{mg} / \mathrm{mL}$, the Beer's law is obeyed between the concentration of isoniazid and the absorbance, the linear regression equation is $\mathrm{A}=0.0251+138.04 \mathrm{C}(\mathrm{mg} / \mathrm{mL})$ and the correlation coefficient is 0.9995 .

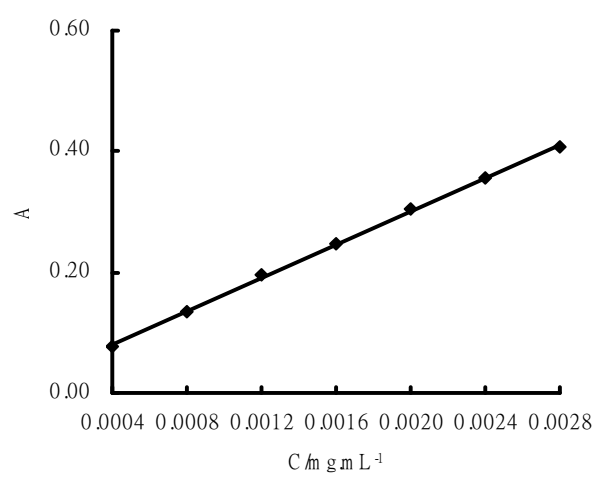

Figure 5. Standard curve

$\mathrm{Fe}^{3+}$ solution:1.40 mL; BPY solution:0.30 mL; pH 5.0 buffer solution: $4.00 \mathrm{~mL}$; reaction temperature: $80^{\circ} \mathrm{C}$; reaction time:30 min; placing time: $10 \mathrm{~min}$.

\subsection{Sample analysis}

20 tablets of isoniazid tablet are weighed $2.4039 \mathrm{~g}$, $0.5098 \mathrm{~g}$ powder of isoniazid tablet is weighed precisely after grinding and biending. The powder of isoniazid tablet is dissolved in bidistilled water and is transferred into a $250 \mathrm{~mL}$ volumetric flask, the solution is diluted to $250.0 \mathrm{~mL}$, mixed well and filtered. $10.00 \mathrm{~mL}$ filter liquid is transferred into a $200 \mathrm{~mL}$ volumetric flask, then this filter liquid is diluted to $200.0 \mathrm{~mL}$ with bidistilled water, mixed well. This is the isoniazid sample solution, and the solution is preserved at $4^{\circ} \mathrm{C}$, shielding from light.

When isoniazid sample solution $(0.30 \mathrm{~mL}), 0.2000$ $\mathrm{mg} / \mathrm{mL} \mathrm{Fe}{ }^{3+}$ solution(1.40 mL), $0.01998 \mathrm{moL} / \mathrm{L} \mathrm{2,2'-}$ bipyridine solution $(0.30 \mathrm{~mL})$ and $\mathrm{pH}=5.0$ buffer solution $(4.00 \mathrm{~mL})$ are added. Based on the experimental method, the content of the isoniazid in isoniazid tablet is determined by controlling the reaction temperature is $80^{\circ} \mathrm{C}$, reaction time is $30 \mathrm{~min}$ and placing time is $10 \mathrm{~min}$. Meanwhile, the recovery tests of standard addition are performed and the content of isoniazid in isoniazid tablet is determined by pharmacopoeia method. The results as show in Table 3.

Table 3 The content of isoniazid in isoniazid tablets $n=5$

\begin{tabular}{|c|c|}
\hline Sample & Isoniazid tablet \\
\hline Proposed method $\left(\mathrm{mg} \cdot\right.$ tablet $\left.^{-1}\right)$ & 100.7 \\
\hline RSD $(\%)$ & 1.3 \\
\hline $\begin{array}{c}\text { Pharmacopoeia method }[13] \\
\left(\mathrm{mg} \cdot \text { tablet }^{-1}\right)\end{array}$ & 96.1 \\
\hline Added $\left(\mu \mathrm{g} \cdot \mathrm{mL}^{-1}\right)$ & 0.4000 \\
Recovered $\left(\mu \mathrm{g} \cdot \mathrm{mL}^{-1}\right)$ & 0.8000 \\
\hline Recovery $(\%)$ & 0.3997 \\
& 0.7724 \\
\hline
\end{tabular}

It is seen from table 3 that the content of isoniazid in isoniazid tablet is $100.7 \mathrm{mg} \cdot$ tablet $^{-1}$ by this proposed method, and the content of isoniazid in isoniazid tablet is $96.1 \mathrm{mg} \cdot$ tablet $^{-1}$ by pharmacopoeia method. It shows that the two results are similar. It is indicates that the content of isoniazid in isoniazid tablet can be accurately determined by $\mathrm{Fe}$ (II)-2,2'-bipyridine spectrophotometry.

\section{Conclusion}

In this paper, a new method for the determination of isoniazid by $\mathrm{Fe}(\mathrm{II})-2,2$ '-bipyridine spectrophotometry is reported. This method has been successfully used for the determination of isoniazid in isoniazid tablets, and the results are similar to the results of pharmacopoeia method. It is clearly obvious that the determination of isoniazid by $\mathrm{Fe}$ (II)-2,2'-bipyridine spectrophotometry has certain practical significance and application prospect. 


\section{References}

[1] ZARGAR B, HATAMIE A . (2013) Localized Surface Plasmon Resonance of Gold Nanoparticles as Colorimetric Probes for Determination of Isoniazid in Pharmacological Formulation[J]. Spectrochim. Acta. A., 106:185-189.

[2] ZHANG H, WU L L, LI Q M, et al . (2008) Determination of isoniazid among pharmaceutical samples and the patients' saliva samples by using potassium ferricyanide as spectroscopic probe reagent[J]. Anal. Chim. Acta., 628: 67-72.

[3] RUI A S L, JOSE L F C L, JOAO L M S. (2000) Fluorimetric Determination of Isoniazid by Oxidation with Cerium(IV) in a Multicommutated Flow System[J]. Anal. Chim. Acta., 419: 17-23.

[4] HAGHIGHI B, BOZORGZADEH S. (2010) Flow Injection Chemiluminescence Determination of Isoniazid using Luminol and Silver Nanoparticles [J]. Microchem. J., 95: 192-197.

[5] LIU Y, FU Z F, WANG L. (2012) Capillary Electrophoresis Analysis of Isoniazid using Luminol-peridoate Potassium Chemiluminescence system[J]. Luminescence., 26(6):397-402.

[6] ZHANG X F, XUAN Y L, SUN A M, et al. (2009) Simultaneous Determination of Isoniazid and pAminosalicylic Acid by Capillary Electrophoresis using Chemiluminescence Detection[J]. Luminescence., 24: 243-249.

[7] KHUHAWAR M Y, ZARDARI L A. (2008) Ethyl Chloroformate as a Derivatizing Reagent for the Gas Chromatographic Determination of Isoniazid and Hydrazine in Pharmaceutical Preparations[J]. Anal. Sci., 24: 1493-1496.

[8] CHELlini P R, LAGES E B, F R ANCO P H C, et al. (2015) Development and Validation of an HPLC Method for Simultaneous Determination of Rifampicin, Isoniazid, Pyrazinamide, and Ethambutol Hydrochloride in Pharmaceutical Formulations[J]. J. Aoac. Int. 98(5):1234-1239.

[9] AYYAPPAN J , UMAPATHI P , QUINE S D . (2011) Development and Validation of a Stability Indicating High-performance Liquid Chromatography (HPLC) Method for the Estimation of Isoniazid and its Related Substances in Fixed Dose Combination of Isoniazid and Ethambutol Hydrochloride Tablets[J] . Afr. J. Pharm. Pharmacol., 5(12):1513-1521.

[10] ABSALAN G, AKHOND M, SOLEIMANI M, et al. (2016) Efficient Electrocatalytic Oxidation and Determination of Isoniazid on Carbon Ionic Liquid Electrode Modified with Electrodeposited Palladium Nanoparticles[J]. J. Electroanal. Chem., 761:1-7.

[11] RASTOGI P K, GANESAN V, AZAD U P. (2016) Electrochemical Determination of Nanomolar Levels of Isoniazid in Pharmaceutical
Formulation using Silver Nanoparticles Decorated Copolymer[J]. Electrochimica. Acta., 188:818824.

[12] CHANG W B, LI K A. (1981) Brief Handbook of Analytical Chemistry[M]. Beijing:Beijing University Press, 262. (In Chinese)

[13] Chinese Pharmacopoeia Commission. (2015) Pharmacopoeia of People's Republic of China (2015 edition, two) [M]. Beijing:China Medical Science Press, 413. (In Chinese) 